\title{
直接撮影用自動露出機構の特性と炎の現状
}

東邦大学医学部附属大橋病院放射線部

\author{
宮 崎茂 \\ 日本鋼管病院放射線科 \\ 斎 藤 一 彦 \\ 東邦大学医学部放射線医学教室 \\ 青 柳 泰 司 \\ （論文受理１984年 7 月 1 日） \\ （最終論文受理１985年 7 月19日） \\ (Code No. 495. 4)
}

Key words: Automatic density control system for direct radiography ; Performance survey ; Combination with 2-peak and 12-peak generators; Thickness, Tube voltage, and Time characteristics; Normal performance

\section{PERFORMANCE OF AUTOMATIC DENSITY CONTROL SYSTEM FOR DIRECT RADIOGRAPHY AND THE PRESENT STATE}

\section{SHIGERU MIYAZAKI}

Department of Radiology, Ohashi Hospital Attached to the School of Medicine, Toho University

$$
\text { KAZUHIKO SAITO }
$$

Department of Radiology, Nippon Kokan Hospital

\section{TAIZI AOYAGI}

Department of Radiology, School of Medicine, Toho University

(Article received; Jul., 1, 1984)

\section{Summary}

Performance of daily using 36 automatic density control systems for direct radiography, the so-called photo-timing units, being widely accepted in Japan recently was tested by users employing three measuring criteria: phantom thickness, X-ray tube voltage and time response. In addition, normal performance of the typical units among them are discussed. 
Fourteen units were tested in 1977 and twenty two units in 1982 . According to the test results, there were 3 units in 1977 and 4 in 1982 that had normal performance.

Actual performance of the automatic density control system for direct radiography is influenced by the dynamic characteristics of the coupled X-ray generators. Looked at from this viewpoint, the generator dynamic characteristics were measured. The fundamental characteristics were discussed in connection with the responses from these generators, and the normal performance of these units is given in the following figures.

\section{1. 緒言}

$\mathrm{X}$ 線直接撮影の適正な撮影条件は被写体のX線吸収に 応じて決定されるが，通常撮影する場合その被写体に合 つた適正露出を前もって予測し，それに適したX線を曝 射することは難しく人的誤差が大きい。これを補う目的 で自動露出機構は考案された。自動露出機構はX線検出 部と制御回路により構成され，これをX線発生装置と組 合せ被写体透過後のX線強度に応じて曝射時間あるいは 入射 $X$ 線強度が制御され，被写体吸収の変化に対して常 に同一濃度のX線写真を得るものである。本稿では自動 露出機構のうち直接撮影用時間制御のものを対象とする. 直接撮影用自動露出機構の基本的な考え方は開発当初 から現在まで変わらないが, X線検出器, 制御回路等の 特性に大きな向上が見られる。一方これと組合せるX線 発生装置の進歩は著しく，現在のX線嚗射時間はミリ秒 単位で正確に制御することが可能となった。こうした中 で自動露出機構の普及率は日本放射線技術学会東京部会 X線装置研究会の調査によると1977年には79\%，1982年 では $91 \%$ に達している1),2).

1977年東京部会X線装置研究会が行った特性調査（14 台 $\left.^{3)}\right)$ ，および1982年東京部会が行った第 4 回集談会にお いて部会員が測定した自動露出機構22台4)，合計36台の 自動露出機構についてユーザによる動作特性測定結果を まとめることができた。一方そこで得られた諸特性につ いては各装置間のみならず同一機種の自動露出機構間に おいても大きな開きが認められた。これについて同型の 自動露出機構について管電圧, 管電流計オシロスコープ 等を接続し，より詳しく諸特性の測定を行い結果を検討 し考察を加えたので報告する。

\section{2. 調 査}

\section{1 調査方法および結果}

$\mathrm{X}$ 線装置研究会が行った調査方法は会員施設にアクリ ル板ファントムを持ち回り，撮影条件として管電圧 80 , $120 \mathrm{kV}$, 管電流 $100,200 \mathrm{~mA}$, 照射野 $30 \times 30 \mathrm{~cm}$ を選び 1 種類のフィルムを使用しアクリル厚 $5 \mathrm{~cm}$ から $25 \mathrm{~cm}$
についてそれぞれ自動露出撮影を行い，写真濃度を測定 し自動露出機構の動作特性を調べた。これから当時の自 動露出機構の動作特性は被写体厚の薄い短時間領域では 濃度が高く，被写体厚の厚い長時間領域では濃度が低下 する傾向を示し，また管電圧による濃度差も大きくかな らずしも満足すべき状態になっていないという知見を得 $た^{3)}$.

集談会に扔ける方法は部会員が各施設でテストI被写 体厚特性（管電圧，管電流を一定にし被写体厚を変え る)，テストII管電圧特性(被写体厚，管電流を一定にし 管電圧を変える)，テストIII応答時間特性(被写体厚，管 電圧を一定にし管電流を変える）について実験した。 22 台の自動露出機構の結果はテスト I では濃度差0.2以内 に納まる装置は 7 台，0.4以内に入る装置は 4 台，0.4以 上の装置は11台であった。テストIIでは濃度差0.2以内に 納まる装置は 6 台，0.4以内に入る装置は 5 台，0.4以上 の装置 9 台であった.テストIIIでは0.2以内に納まる装置 は 11 台，0.4以内に入る装置は 3 台，0.4以上の装置は 5 台であった。その内代表的な 4 種類の装置について Fig. 1 に特性を示す。テストIは実線，テストIIは一点鎖線， IIIは破線で示し濃度は太線，mAs，ms は細線で表わす。

\section{2 小 括}

臨床的に許容される濃度差を 0.2 (胸部写真で濃度差が 判読できる值）とし，使用上問題ないと考えられる装置 は1977年では 3 台，1982年は 4 台でありこの間 5 年経過 しているが大差なくあまりよくなったとは言えない。こ こでこの問題がどこにあるかを明らかにする目的で各機 種の標準となる特性について考察する。

\section{3. 自動露出機構の標準的と考えられる 特性 ${ }^{5)}$}

自動露出機構の基本特性には応答時間特性，管電圧特 性，被写体厚特性がある。その中で応答時間特性は組合 せるX線発生装置の主回路開閉機構の応答特性に大きく 左右される。そこで同種の自動露出機構に主回路制御の 異なるX線発生装置の組合せを例にとり，その特性の相 違について考察を加える。 

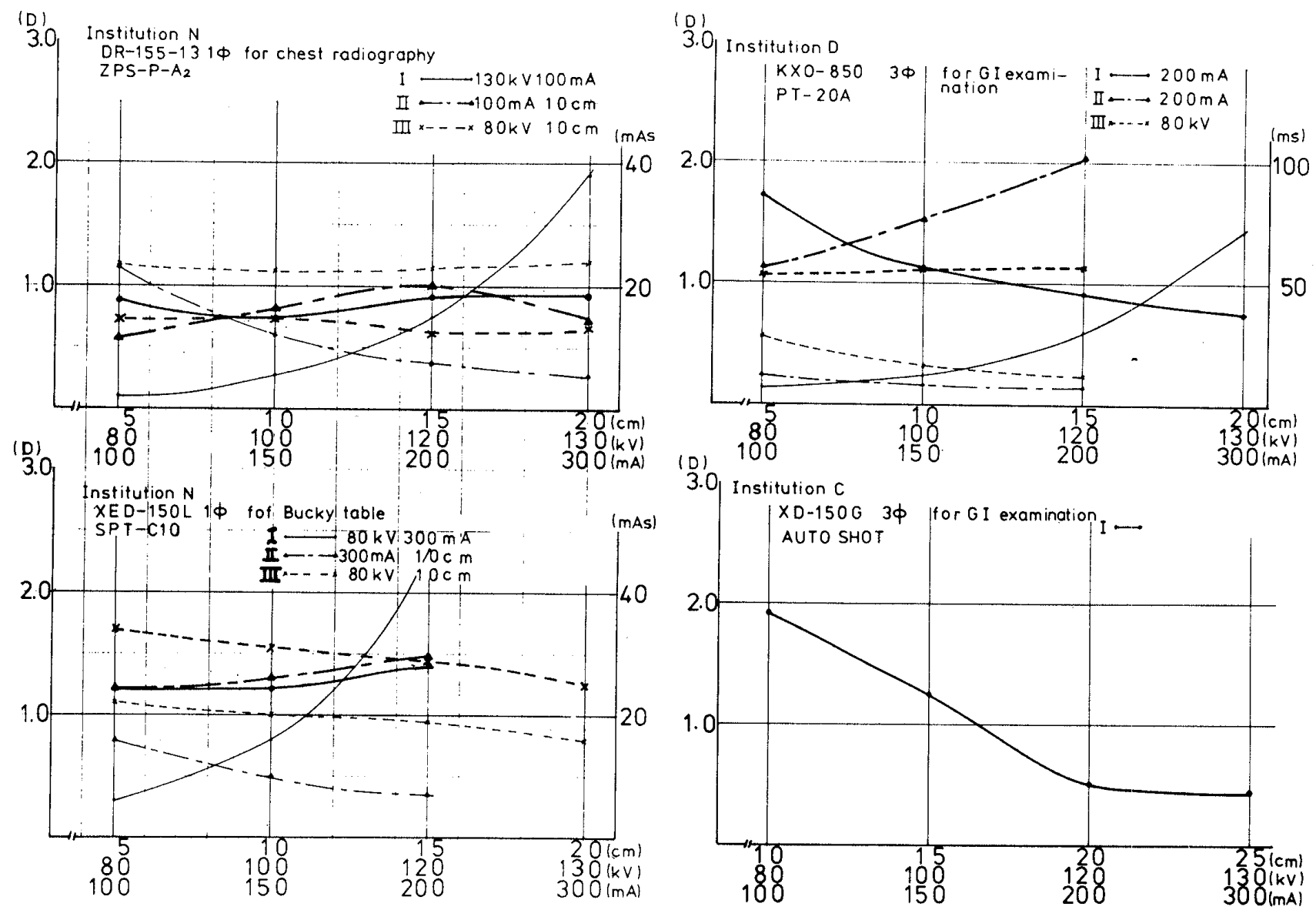

Fig. 1 Survey II (1982)

These charts were proposed by technologists attended to the JSRT Tokyo workshop to discuss the test results, respectively.

Test I: Phantom thickness and film density characteristics

Test II : Tube voltage characteristics

Test III : Time response

特性図について実線は濃度，破線は曝射時間，オシロ グラムは管電圧，管電流，蛍光強度，X線停止信号の各 波形である。このオシログラムにより被写体厚に応じた 自動露出機構の動作全体を判定した。

\section{1 単相装置との組合せ (自動露出機構 PT-21A, X} 線発生装置 KXO-15V)

この装置は透視撮影台に組込まれX線の検出はX線蛍 光増倍管の蛍光出力で行っている.この設定の場合天板, 増感紙圧着板等のX線吸収特性, 感光材料系, $X$ 線蛍光 増倍管の線質特性により線質依存性が大きくなる傾向に ある6). Fig. 2 は被写体厚と濃度，曝射時間について表わ したものである，横軸はアクリル板の厚さ，縦軸は濃度 （左）扔よび曝射時間（右）である。被写体厚特性を見る と管電圧 $80 \mathrm{kV}$ では $8 \mathrm{~cm}, 90 \mathrm{kV}$ では $11 \mathrm{~cm}, 100 \mathrm{kV}$ で は12 cm から濃度は平坦となっている．被写体厚の薄い

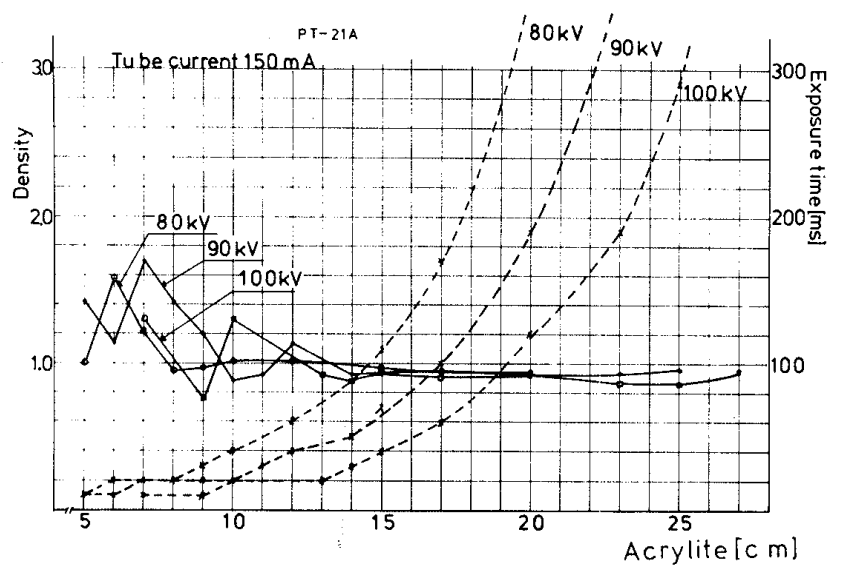

Fig. 2 Performance of photo timing unit coupled with the thyristor controlled 2 peak generator. 


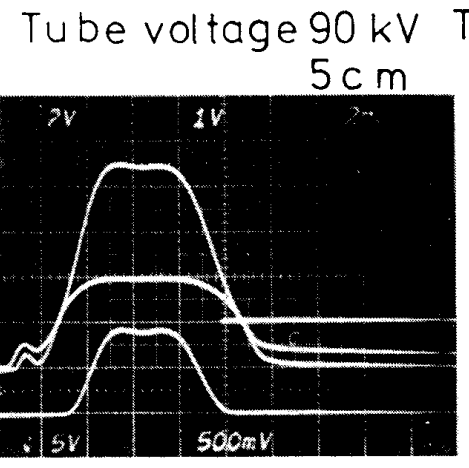

$9 \mathrm{~cm}$

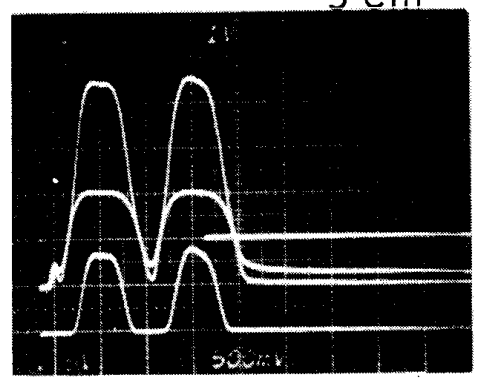

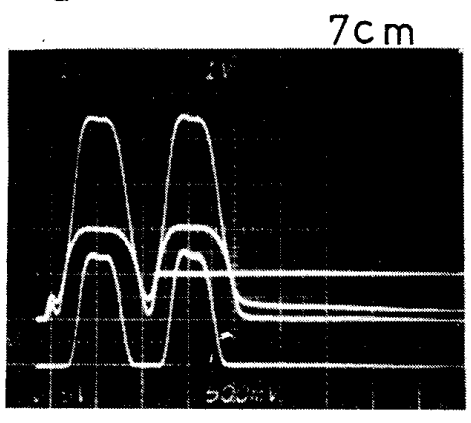

$10 \mathrm{~cm}$

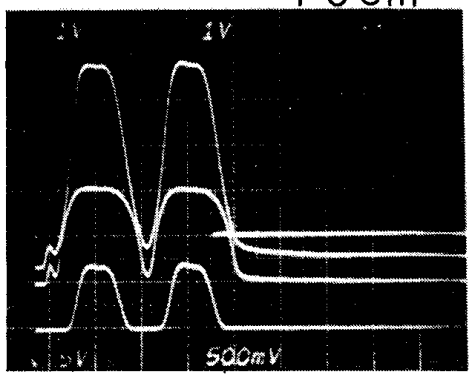

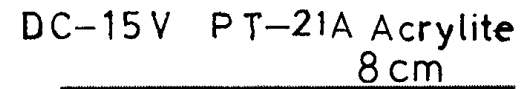

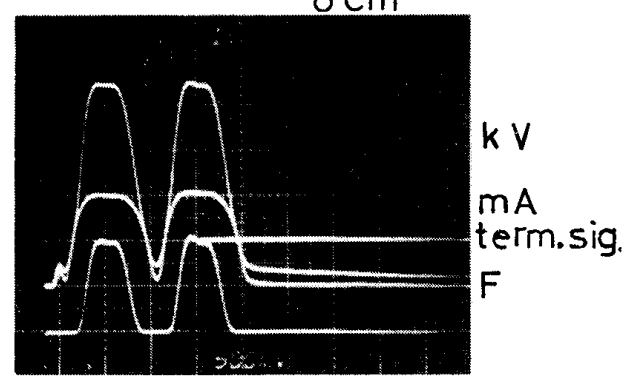

$11 \mathrm{~cm}$

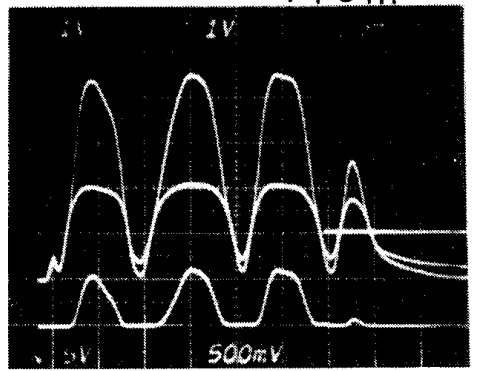

Fig. 3 Relation between the X-ray termination signal from the photo-timing unit and $\mathrm{X}$-ray pulse termination timing.

短時間領域では濃度がジグザグ状に変化している。この 現象は主回路サイリス夕制御特有なもので電源周波数 50 $\mathrm{Hz}$ の場合曝射時間が $10 \mathrm{~ms}$ 毎のパルス状に変化するた めである。この現象を理論的にみると被写体厚と濃度の 関係は被写体厚の薄いところで濃度はのこぎり歯状の変 化を示し，厚さが厚くなるに従い減衰していくものであ る. Fig. 3 は管電圧 $90 \mathrm{kV}$, 管電流 $150 \mathrm{~mA}$ におる主回 路の動作特性を表したもので上から管電圧, 管電流, X 線停止信号, 蛍光強度波形である.アクリル板 $7 \mathrm{~cm}$ では $\mathrm{X}$ 線停止信号が10 ms を極僅か越えたため写真効果（蛍 光強度波形）は10 $\mathrm{ms}$ で良いにもかかわらず $20 \mathrm{~ms}$ とな っている。またアクリル板厚が $7 \mathrm{~cm}$ から $10 \mathrm{~cm}$ と厚く なりX線停止信号は応答してるにもかかうらず曝射時間 は変化しない.このように自動露出機構は応答時間に限 界があり特性を調べる場合濃度とともに曝射時間との関 係が重要な意味を持つ。この自動露出機構の最短応答時 間は0.04秒である。この形の自動露出機構は管電圧特性, 短時間, 長時間曝射について補償回路がありそれらは良 好に調整されている。

\section{2 三相装置との組合せ}

a . 三相装置一（1 次側主回路サイリス夕逆並列制御

型. 自動露出機構 ZPS-P-A3，X線発生装置 DH-1513A） この自動露出機構はX線検出部が増感紙フィルム系よ
りX線入射側にある前面検出型でブッキー撮影台に組込 まれている。自動露出機構の特性はアクリル板の薄い短 時間曝射領域で濃度変化は大きく，㕌くなるに従い濃度 変化は減少している (Fig.4).アクリル板 $18 \mathrm{~cm}$ で管電 圧依存性を見ると管電圧 $60 \mathrm{kV}$ から $100 \mathrm{kV}$ で濃度差は 0.4 である.短時間領域で濃度変化の大きな原因は自動露 出回路内のリレーの応答遅れ，電源周波数 $50 \mathrm{~Hz}$ の場合 $\mathrm{X}$ 線制御が $3.3 \mathrm{~ms}$ 毎になりその遅れによるものである. Fig. 5 はこの装置の動作を示したオシログラムで上から

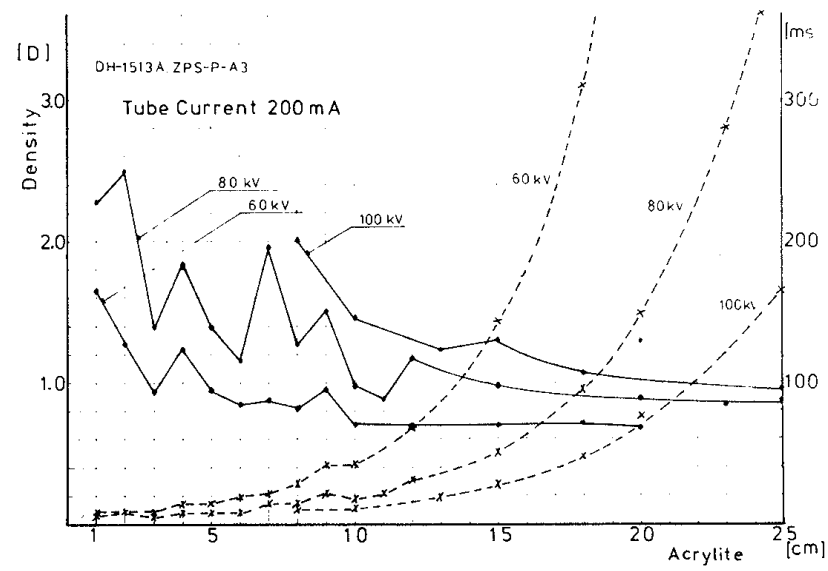

Fig. 4 Performance of photo timing unit coupled with a conventional 12 peak generator. 
DH-1513A ZPS-P-A3

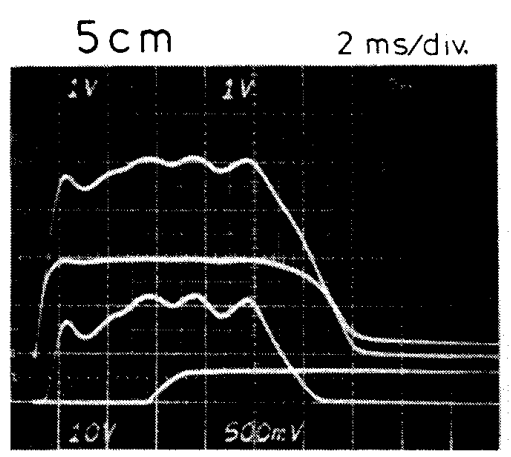

$9 \mathrm{~cm}$

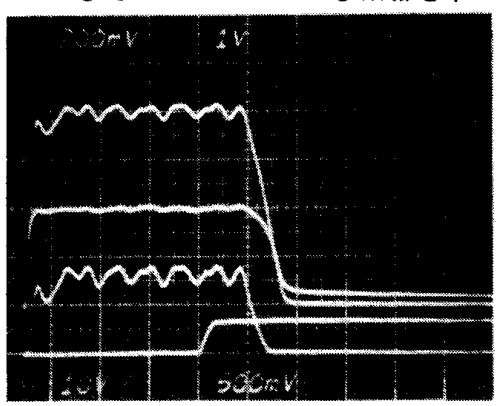

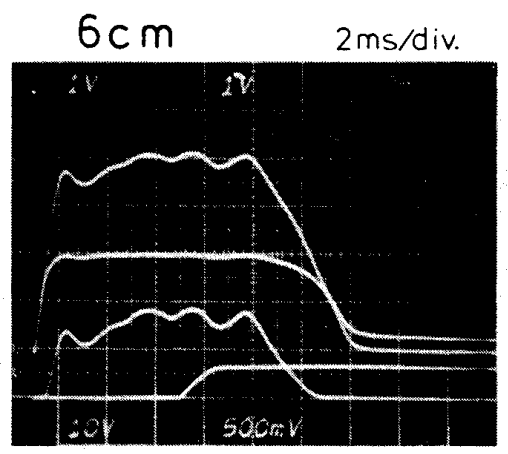
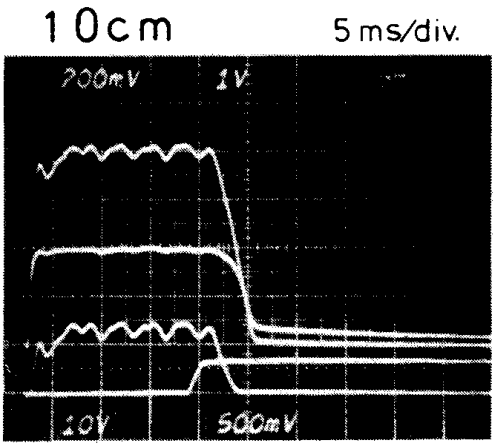

$80 \mathrm{kV} 200 \mathrm{~mA}$
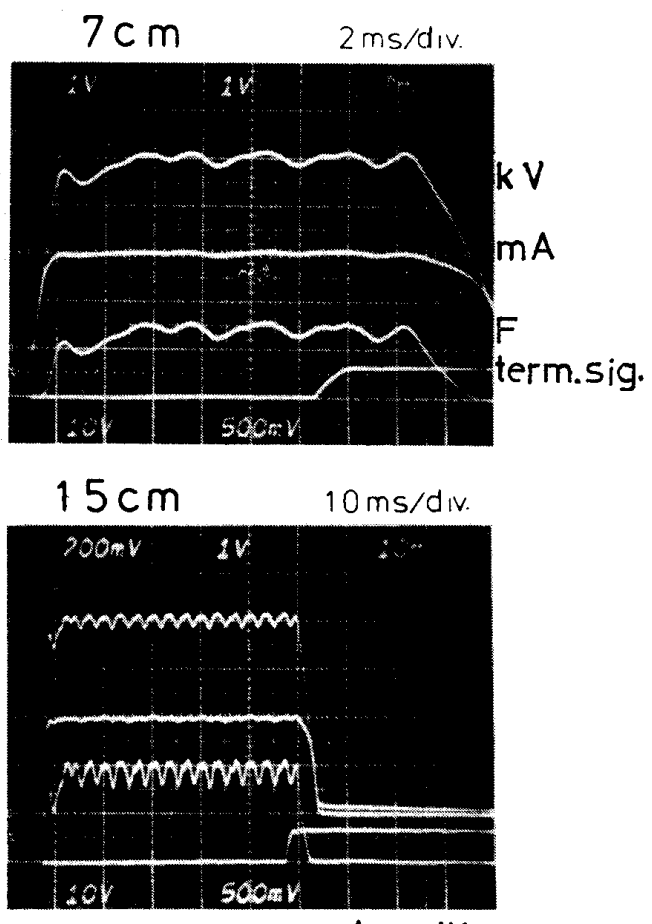

Acrylite

Fig. 5 Relation between the termination signal from photo-timing unit and X-ray termination. From top to bottom, X-ray tube voltage, current, fluorescence intensity waveforms and termination signal.

管電圧, 管電流, 蛍光強度, $\mathrm{X}$ 線停止信号の各波形であ る.アクリル板 $5 \mathrm{~cm}$ より $6 \mathrm{~cm}$ の方がX線停止信号は伸 びているが曝射時間は変わっていない、またアクリル板 $10 \mathrm{~cm}$ においては自動露出制御回路の応答およびX線発 生装置の応答遅れ両方が早期に応答している。この自動 露出機構の応答遅れは約 $5 \mathrm{~ms}$ あり, この遅れ時間が短 時間曝射領域で大きな濃度変化となる。この自動露出機

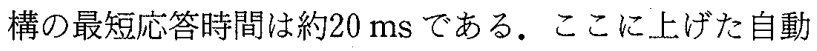
露出機構は管電圧特性, 短時間領域, 長時間領域に対す る補償回路がなく, その意味では自動露出機構の各特性 を顕著に表わしているといえる。

b. 三相装置一 2 (高速遮断 ${ }^{6}$ ) 自動露出機構 SPT.C10, X線発生装置 HD150G-40)

ここに上げる自動露出機構は X $\mathrm{X}$ 線検出部がフィルムチ エンジャに組込まれ, 増感紙フィルム系よりX線入射側 で検出する前面検出型で主に胸部撮影に使用している。 被写体厚特性はアクリル板 $5 \mathrm{~cm}$ から $25 \mathrm{~cm}$ まで濃度変 化は極僅かで良好といえる(Fig.6). 自動露出機棈と組 合せるX線発生装置は自動露出制御回路からのX線停止 信号に即応して，管電圧を写真効果のない不感電圧まで 下げ主回路応答遅れをできるだけ短かくする高速遮断回

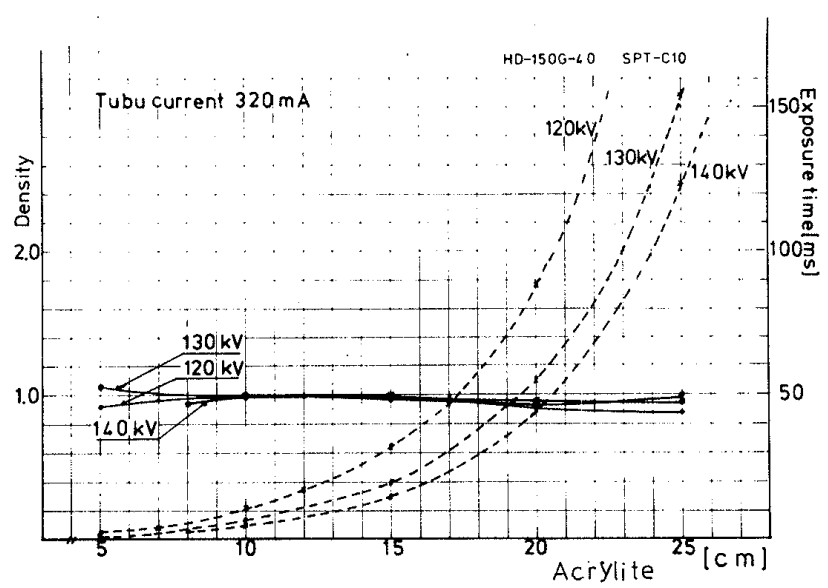

Fig. 6 Performance of photo timing unit with the rapid interrupter.

路を有している.Fig.7はこれを動作させたときの管電 圧, 管電流, $\mathrm{X}$ 線停止信号, 蛍光強度波形である. 遮断 回路が動作すると管電压は急速に降下し写真効果はほと んど無視できる值まで減少していることを示している。 これにより主回路応答遅れは $1 \mathrm{~ms}$ となり短時間応答特 性は大いに向上している. 装置の最短応答時間は約 $3 \mathrm{~ms}$ である，管電圧による濃度差はほとんどない。これは管 


\section{$H D-150 G-4 C S P T-C: C$}
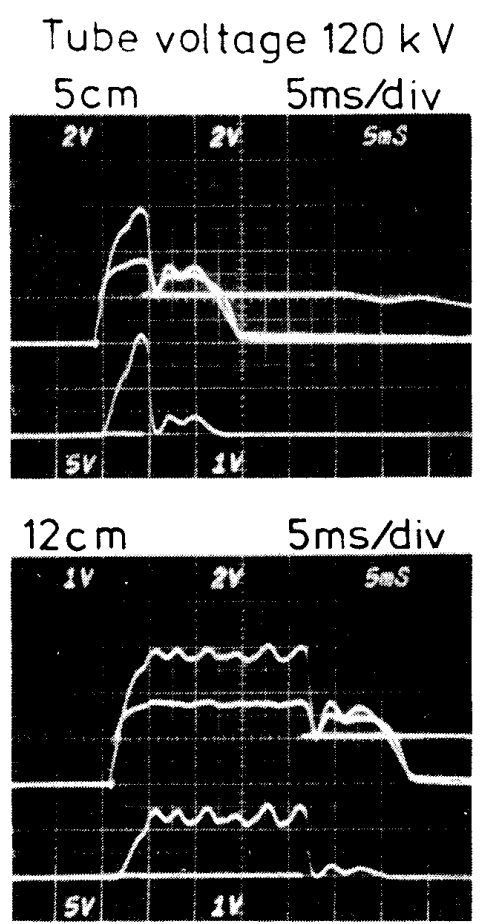

Tube current $320 \mathrm{~mA}$
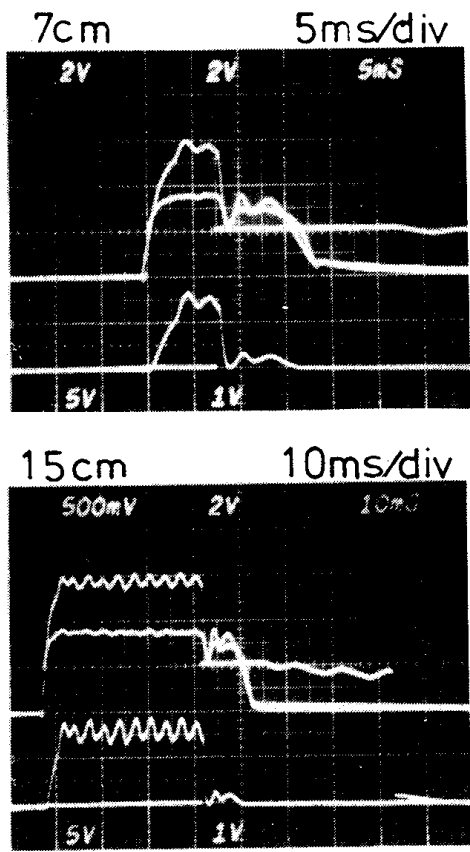
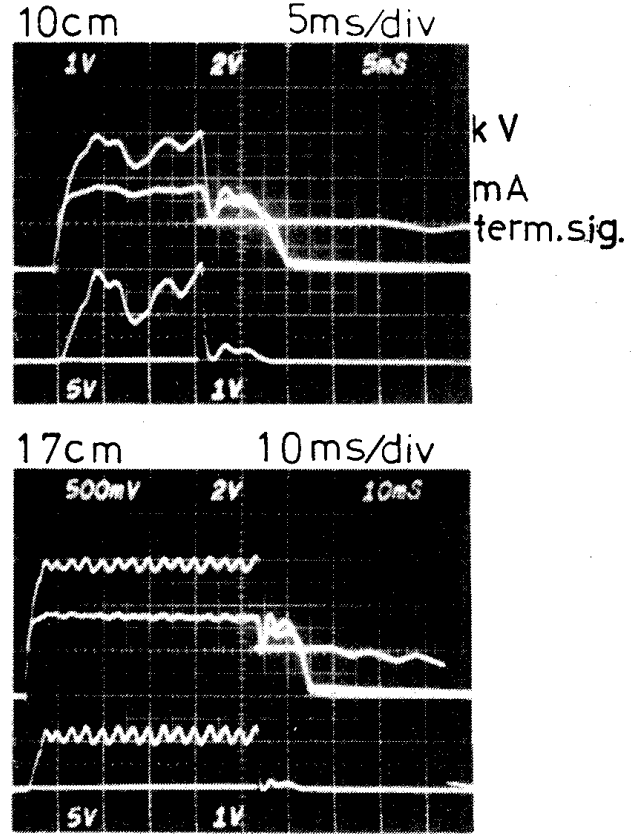

Acrylite

Fig. 7 Relation between termination signal and rapid interrupter.
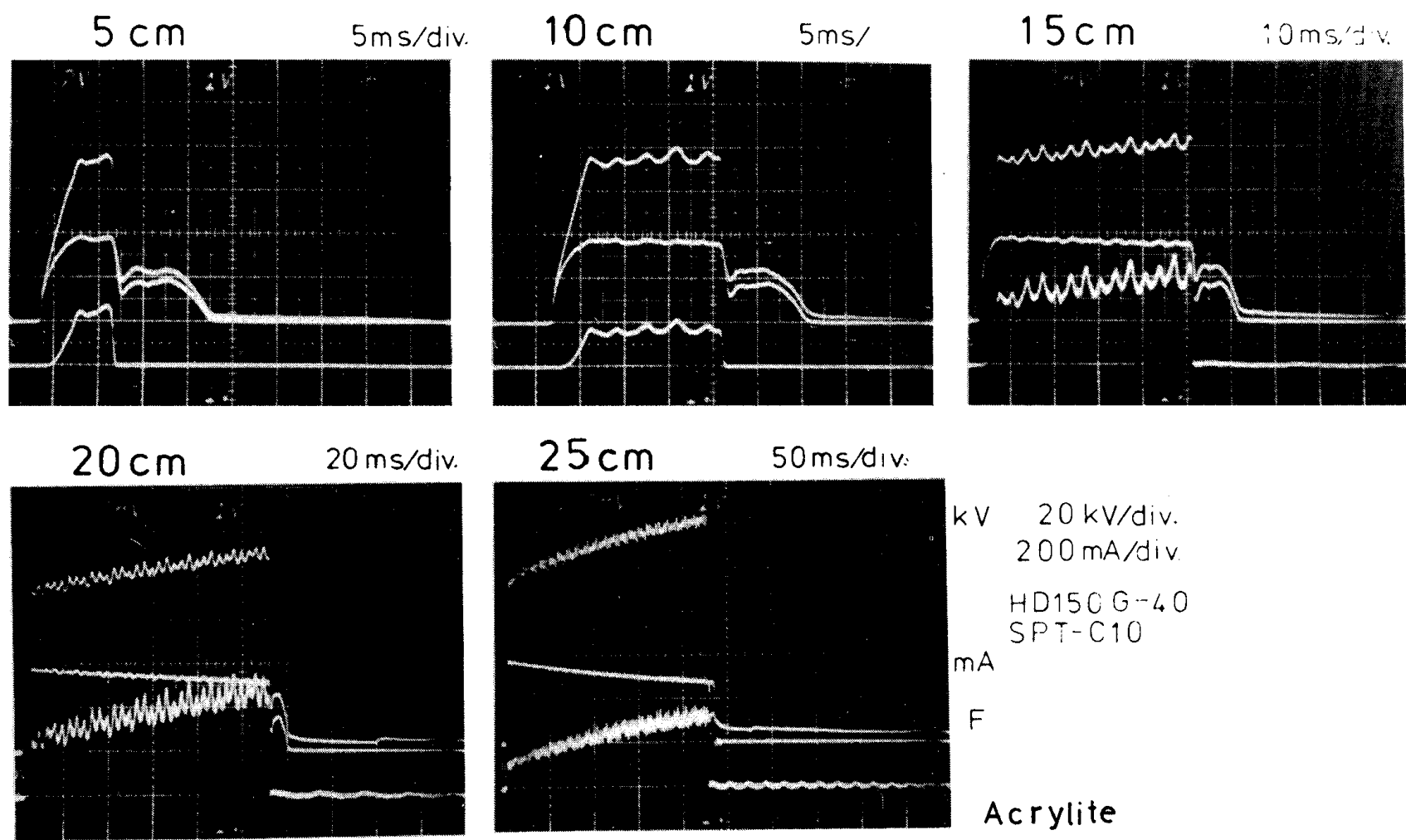

Fig. 8 Auto shot with a rapid interrupter. X-ray tube voltage and current change within an exposure duration. 
電圧が $120 \mathrm{kV}$ 以上と高いためX線検出部の自己吸収が 少ないためである。

c. 三相装置一 3 (auto - shot 自動露出機構 SPT-

$\mathrm{C} 10, \mathrm{X}$ 線発生装置 HD150G-40)

自動露出機構は多方向消化管透視撮影台に組込まれて いる。一般的な自動露出機構（ホトタイマ）は曝射時間 制御のため吸収体厚に適した管電圧, 管電流值を設定し なければ，極端に曝射時間が短かくなり応答時間の限界 を越えたり，曝射時間が長くなり運動ボケを起こす原因 になる、オートショット方式は吸収体厚変化に応じ変化 する曝射時間の変化幅をできる限り少なくする目的で考 えられた装置である．Fig. 8 は装置を動作させたときの 管電圧，管電流，蛍光強度波形である。またX線発生装 置は短時間応答を良くする目的で高速遮断を有している. 管電圧変化は曝射時間 0.25 秒内で管電流を $380 \mathrm{~mA}$ から $280 \mathrm{~mA}$ に減少させることで管電圧 $70 \mathrm{kV}$ から $110 \mathrm{kV}$ まで増大させている，このようにオートショット方式は 通常の自動露出機構に比べ有利な点もあるが吸収体厚変 化による画質を選べない不便もある．Fig. 9 は自動露出 機構の特性を表わしたもので被写体厚特性はアクリル板 $5 \mathrm{~cm}$ から $25 \mathrm{~cm}$ の濃度変化は約 0.18 と良好であり, 最短 応答時間は $3 \mathrm{~ms}$ である。

d. 三相装置一 4 (強制消弧サイリスタ制御6) 自動露

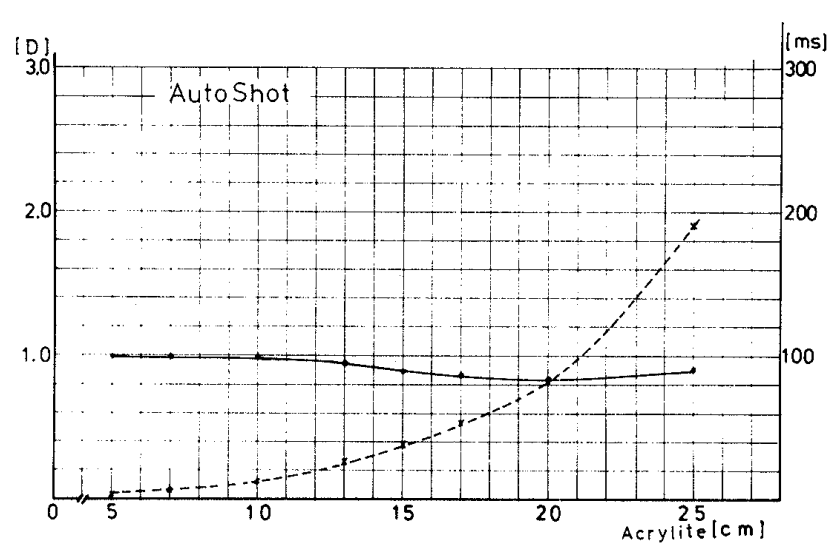

Fig. 9 Performance of the auto shot.

出機構 PT-20A-C, X線発生装置 KXO-1250A 特)

自動露出機構はX線検出部が立形ブッキ撮影台に組込 まれ，胸腹部および胸腰椎の撮影に使われている．X線 発生装置は一次側サイリス夕制御であるが，サイリス夕 を強制的に消弧させることで任意な時間でX線を遮断す ることができる.Fig. 10 は自動露出機構を動作させた場 合の管電圧，管電流，蛍光強度，X線停止信号の各波形 である、X線停止信号から約 $1.7 \mathrm{~ms}$ の途れで主回路サイ リス夕は消弧されている，最短応答時間は約 $4 \mathrm{~ms}$ であ る. Fig. 11 は装置の特性を表わしたもので, アクリル板

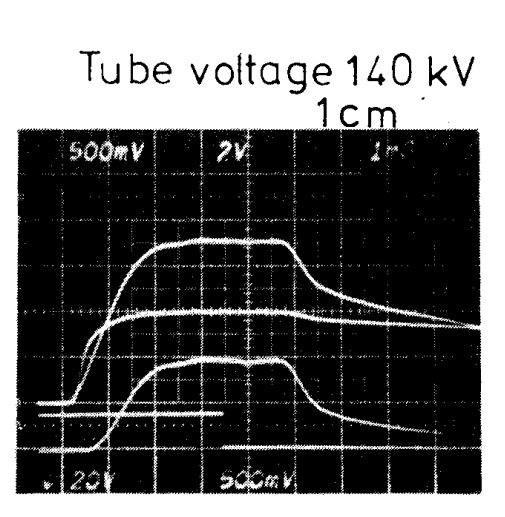

$4 \mathrm{~cm}$

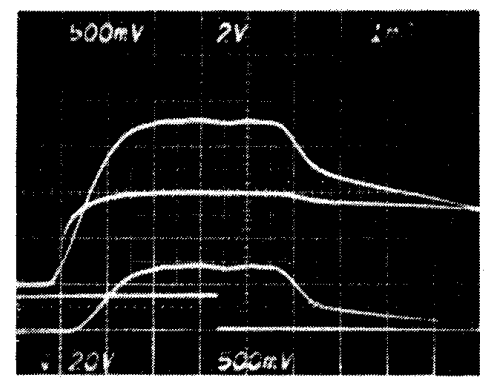

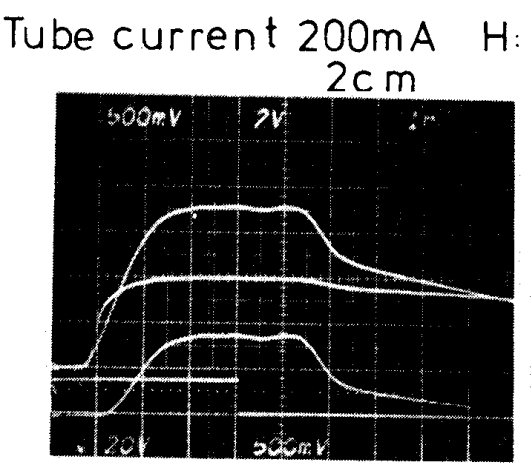

$5 \mathrm{~cm}$

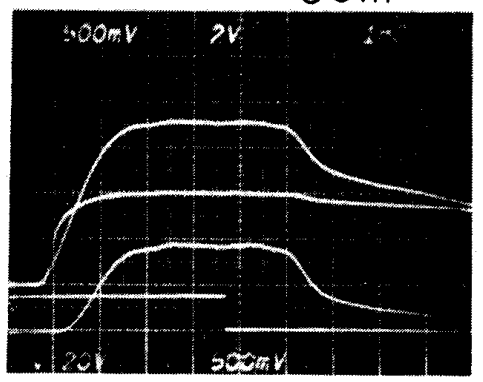

KX0-1250A PT - 20A-C

$\mathrm{H}: 1 \mathrm{~ms} / \mathrm{div}$ Acrylite

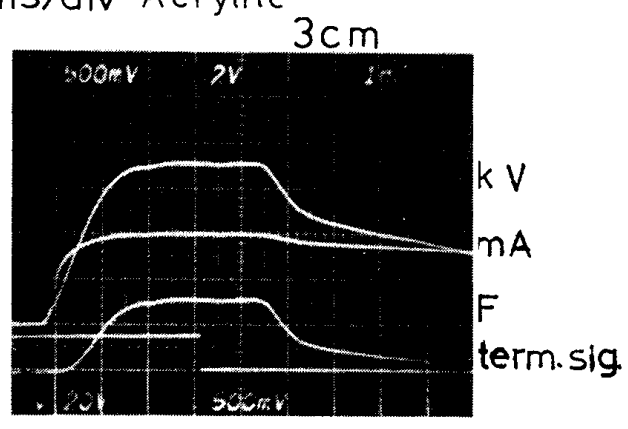

$6 \mathrm{~cm}$

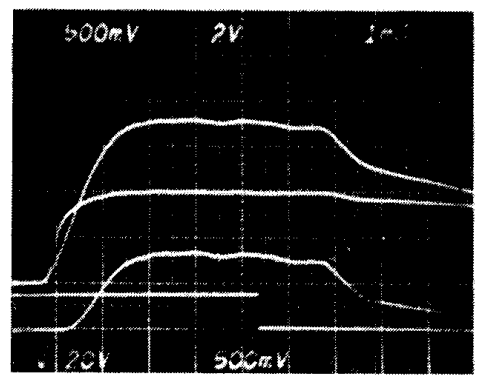

Fig. 10 An example of 12 peak generator with a forced extinguish circuit. It is 1.7 $\mathrm{ms}$ at the termination. 
$5 \mathrm{~cm}$ から $25 \mathrm{~cm}$ で濃度変化は極僅かである.アクリル板 の薄い短時間領域で濃度は連続的に上昇している，この 原因は管電圧波形の立下りの遅れ（高圧コンデンサ，高 圧ケーブルの浮遊容量等による.)によるもので先に述べ た主回路開閉の応答遅れとは異なる。管電圧による濃度

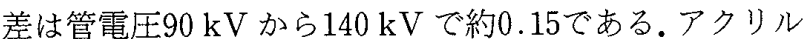
板の厚い比較的曝射時間の長い領域で僅かに濃度が高く なっているが，これは被写体厚補正の過補償によるもの

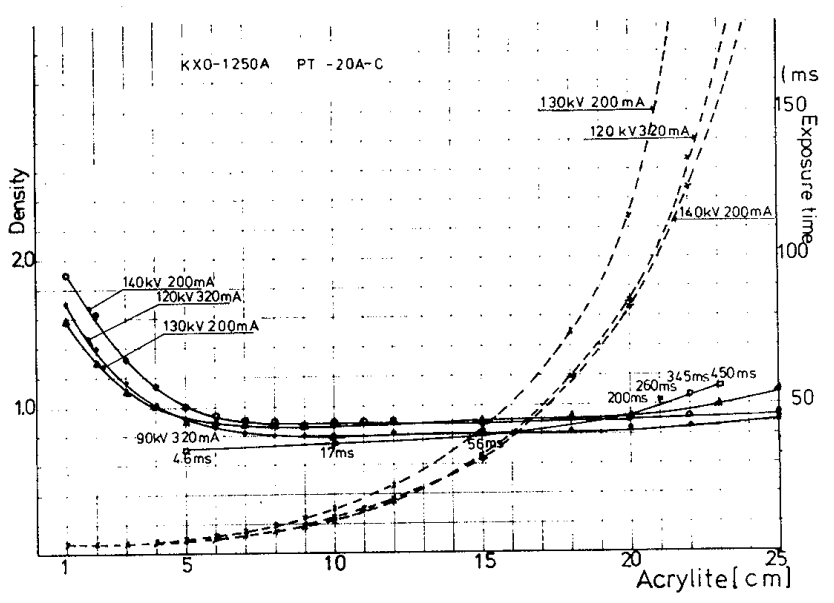

Fig. 11 Performance of the photo-timing unit of a 12-peak generator with a forced extinguish circuit.

\section{$1 \mathrm{~cm}$}

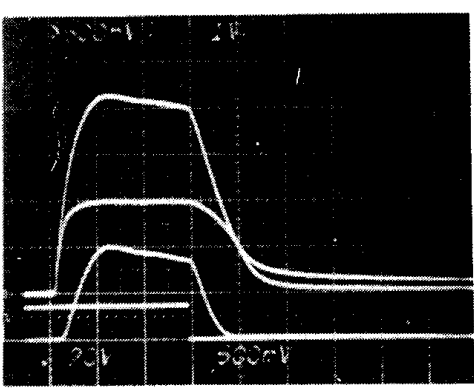

$4 \mathrm{~cm}$
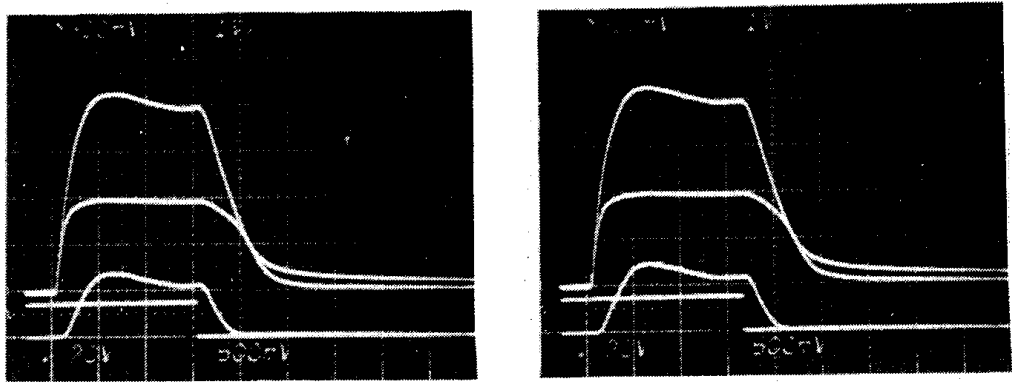

である。

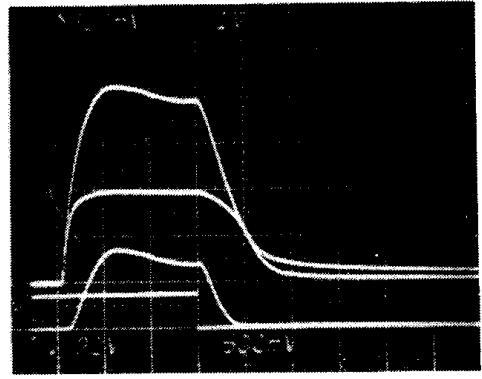

e .三相装置一 5 (二次側スイッチングチューブ制御 ${ }^{6)}$ 自動露出機構 PT-20A-C, X線発生装置 KXO-1250C 特)

自動露出機構は高速フィルムチェンジャにX線検出部 が組込まれ（前面検出）血管撮影等の連続撮影に使われ ている.Fig. 12 は自動露出機構の特性を表わしたもので アクリル板 $7 \mathrm{~cm}$ から $25 \mathrm{~cm}$ まで写真濃度は平坦で良好 な結果を示している、X線発生装置は二次側制御のため

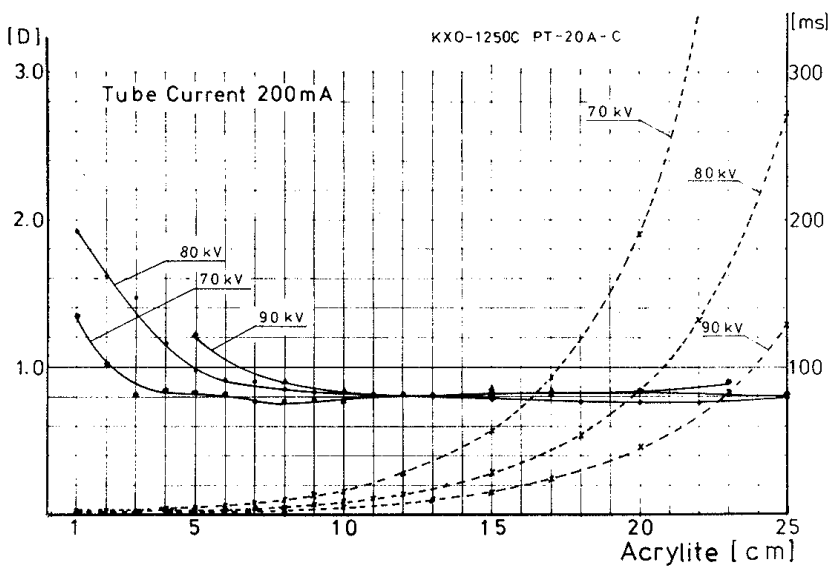

Fig. 12 Performance of a 12-peak generator with switching tetrode tubes. This photo timing unit is used for the head and abdominal angiographic unit.

KXO-1250C PT-20A-C
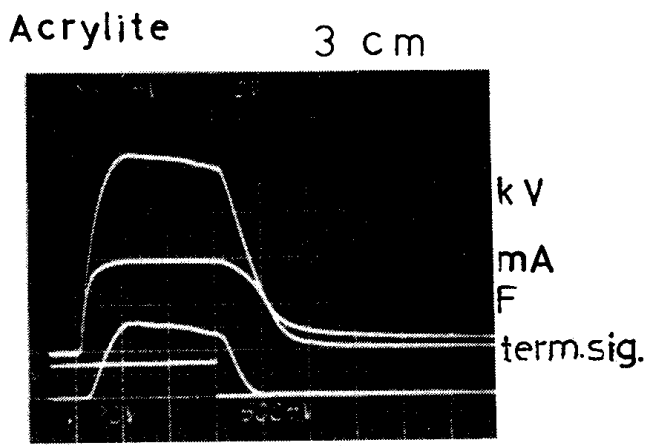

$6 \mathrm{~cm}$

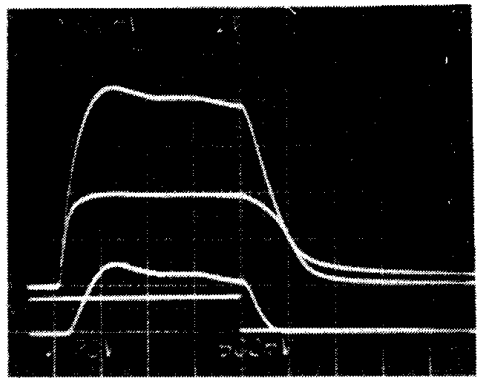

$80 \mathrm{kV} .200 \mathrm{~mA} / 1 \mathrm{~ms} / \mathrm{div}$ !

Fig. 13 An example of a 12-peak generator with switching tetrode tubes. It is $100 \mu \mathrm{s}$ at the termination delay. 
任意な時間でX線制御が可能であり, Fig. 13 は自動露出 機構を稼動させた時の管電圧, 管電流, 蛍光強度, $\mathrm{X}$ 線 停止信号の各波形である. 主回路の応答遅れは $0.1 \mathrm{~ms}$ 程 度で動作している.この場合装置の最短応答時間は約 2.5 msである. Fig. 12 においてアクリル板の薄い短時間曝 射領域での濃度上昇はX線の強曝射により, 自動露出機 構が正常に動作してないためで（Fig. 13 でアクリル板 1 $\mathrm{cm}$ から $4 \mathrm{~cm}$ においてX線停止信号のタイミングが変 わってない.）いままで述べた主回路応答遅れと異なり， 自動露出機構自体の問題として考えなくてはならない. 管電圧変化による濃度差，アクリル板の憬い長時間曝射 領域での濃度変化はいずれも僅かで問題ない.

\section{4 小 括}

自動露出機構の基本的な特性には応答時間特性, 管電 圧特性，被写体厚特性があり，その中で応答時間特性は 自動露出機構が正常に動作していればX線発生装置の主 回路開閉特性によって決定される. 以上の例から求めた 最短応答時間は単相装置の場合 $10 \mathrm{~ms}(50 \mathrm{~Hz})$ の階段状 のX線制御のため $40 \mathrm{~ms}(50 \mathrm{~Hz})$ である。しかしX線発 生装置主回路開閉が強制消弧サイリス夕制御, 高速遮断 機付加の場合, 主回路応答は $5 \mathrm{~ms}$ から可能である ${ }^{3), 6)}$. 三 相装置は一次側制御の場合 $3.3 \mathrm{~ms}(50 \mathrm{~Hz})$ 毎の制御にな るため約 $20 \mathrm{~ms}$ である.しかしこれに高速遮断機が付加 されれば $3 \mathrm{~ms}$, 主回路が強制消弧サイリス夕制御の場合 $4 \mathrm{~ms}$, 二次側制御では $2.5 \mathrm{~ms}$ である。管電圧特性は使用 する増感紙の線質特性とX線検出部に使用する蛍光体の 線質特性によって異なる。しかし実際の自動露出機構に は管電圧依存性の補償回路の有無, またその調整により さまざまな特性が表われる，被写体厚特性についても同 様なことが言える。一般的には被写体厚が厚く曝射時間 が長くなるに従い写真濃度は徐々に低下する。

\section{4. ま と め}

自動露出機構について，本来その装置が持っている性 能を十分活用するために必要な基本特性について述べた。 現在わが国で一般的に使用されている自動露出機構は蛍 光体と光電子増倍管を用いたもので, 基本的な動作は適
正露光 (写真濃度) に相当するX線量に応じ $\mathrm{X}$ 線曝射時 間が制御される自動タイマである。したがって自動露出 機構の特性を論ずる場合，曝射時間の制御方法に注目し なくてはならない.1977年の調査時には総合特性上多く の問題があったが，特にX線発生装置の大半が主回路開 閉に電磁接触器を使用していたため自動露出機構の短時 間応答特性に顕著な濃度のバラツキが表われるなどの問 題が注目された。1982年のテストではX線発生装置の大 部分が主回路サイリス夕制御と変わり短時間応答特性に 表われる濃度のバラツキは解消され最短応答時間も短縮 された。しかしな招自動露出機構の総合的な特性上に大 きな開きが見られた。そこで現在使われている代表的な 機種について，標準と見なされる特性について実際の測 定結果に基づいて検討，考察を加えた。同一機種間で総 合的な特性に大幅な開きが見られる点については基本的 な特性の測定を行い, その装置の動作状態を客観的に認 識することにより，その装置が本来有する標準的な動作 特性に近づけることができると考える。

採光野の問題については人体の被検查部位に対する形 状や配置の適合性がもっとも重要であり，これについて は過去に数多くの研究成果があり本文の適用外と考える。 おわりに貴重な測定資料を提供いただいた東京部会会員, 測 定に協力していただいた東京部会X線装置研究会会員の皆様 に厭く感謝いたします。

\section{文献}

1）渋谷一男，他：アンケートより見た診断用 $\mathrm{X}$ 線装置, 日放技学誌，36(2)，199-208，(1980).

2）中沢靖夫，他：アンケートより見た診断用 X線装置 (第 4 報)，日放技学誌，39(5)，713，(1983)。

3）宮崎茂，他：自動露出装置にお污る時間特性につい て，日放技学誌，34(3)，202-208，(1978).

4）宮崎茂：写真濃度から見た各施設の特性とその検討, 日放技学東京部会雑誌，7，15-18，(1982).

5）斎藤一彦：自動露出機構の基本特性, 日放技学誌, $36(5), 555-567,(1980)$.

6）青柳泰司：診断用 X線装置，コロナ社，(1979). 